\title{
T follicular helper cells in patients with acute schistosomiasis
}

\author{
Yumei Zhang 1,2,3,4,5, Yanjuan Wang ${ }^{1,2,3,4^{*}}$, Yanyan Jiang ${ }^{1,2,3,4}$, Wei Pan ${ }^{6}$, Hua Liu ${ }^{1,2,3,4}$, Jianhai Yin ${ }^{1,2,3,4}$, \\ Yujuan Shen ${ }^{1,2,3,4}$ and Jianping Cao ${ }^{1,2,3,4^{*}}$
}

\begin{abstract}
Background: The role of T follicular helper (Tfh) cells in schistosome infection is not fully defined. In a previous study, a higher frequency of circulating PD- $1^{+} \mathrm{CXCR} 5^{+} \mathrm{CD} 4^{+}$Tfh cells was observed in patients with chronic schistosomiasis relative to healthy controls (HCs) and it correlated positively with the level of soluble egg antigen (SEA) specific antibodies in serum. However, the function of Tfh cells in patients with acute schistosomiasis remains elusive; this was investigated in the present study.

Methods: The frequency of circulating Tfh cells and the expression of inducible T cell co-stimulator (ICOS), programmed cell death 1 (PD-1) and B cell subsets were analyzed in 12 patients with acute schistosomiasis and $10 \mathrm{HCs}$ by flow cytometry. The expression of Bcl6, c-Maf and IL-21 mRNA were detected by quantitative real-time reverse transcriptase PCR (qRT-PCR). The concentration of serum IL-21 and IgG specific to Schistosoma japonicum antigen were then determined by enzyme linked immunosorbent assay (ELISA). Correlations between PD- $1^{+} \mathrm{CXCR} 5^{+} \mathrm{CD} 4^{+}$Tfh cells, memory B cells and IgG specific to S. japonicum were analyzed by Spearman's rank correlation.

Results: The frequency of PD- $1^{+} \mathrm{CXCR}^{+} \mathrm{CD}^{+}$Th and memory $\mathrm{B}$ cells was increased in acute schistosomiasis patients relative to HCs. Moreover, the levels of IL-21 in serum and the expression of IL-21 mRNA were higher in acute schistosomiasis patients. However, there was no significant correlation between PD- $1^{+} \mathrm{CXCR} 5^{+} \mathrm{CD} 4^{+} \mathrm{Tfh}$ cells, memory B cells and IgG specific to $S$. japonicum antigen in patients with acute schistosomiasis.

Conclusions: $\mathrm{PD}-1^{+} \mathrm{CXCR5}^{+} \mathrm{CD} 4^{+}$Tfh cells in peripheral blood are involved in the immune response of patients with acute schistosomiasis. Understanding the immunological mechanism is helpful for the development of vaccination strategies to control schistosomiasis.
\end{abstract}

Keywords: T follicular helper cells, PD-1, IL-21, Acute schistosomiasis

\section{Background}

Schistosomiasis is a serious public health problem in many developing countries. More than 200 million people are infected and 700 million people are at risk of becoming infected $[1,2]$. There is no effective antischistosome vaccine because of insufficient knowledge of immunological responses to schistosomiasis. Humoral immunity is crucial for successful vaccines. Recent studies reveal Tfh cells are a separate subset of $\mathrm{CD} 4^{+} \mathrm{T}$ cells that are mainly responsible for promoting $\mathrm{B}$ cells to undergo proliferation, isotype switching and antibody

\footnotetext{
* Correspondence: wangyanjuan1036@126.com; caojp@yahoo.com ${ }^{1}$ National Institute of Parasitic Diseases, Chinese Center for Disease Control and Prevention, Shanghai 200025, China

Full list of author information is available at the end of the article
}

response [3-5]. Recently, a study showed that Tfh cells were recruited to the liver and upregulated hepatic granuloma formation and liver injury in S. japonicum-infected mice [6]. Our previous study showed that Tfh cells might play an important role in the production of specific antibodies in chronic schistosomiasis patients [7], but their function in acute schistosomiasis patients is unknown.

Although Tfh cells in the germinal center (GC) zones are easily detected, it is difficult to obtain lymph nodes or spleen from schistosomiasis patients. Circulating Tfh cells were reported to share some features of GC Tfh cells [8], thus analysis of circulating Tfh cells may be an effective alternative approach to studying GC Tfh cells in humans. In this paper, we determined the characteristics 
of circulating Tfh cells in acute schistosomiasis patients. PD $-1^{+}$CXCR $5^{+} \mathrm{CD} 4^{+}$Tfh cells were significantly increased and were involved in the immune response. These data contribute to understanding the role of Tfh cells in acute schistosomiasis and will support vaccine development.

\section{Methods}

\section{Ethical statement}

Ethical approval for this study was obtained from the Ethics Committee of the National Institute of Parasitic Diseases, Chinese Center for Disease Control and Prevention (reference no. 2012-12). This study was conducted according to the guidelines provided in the Declaration of Helsinki and all procedures were approved by the Ethics Review Committee of the National Institute of Parasitic Disease, Chinese Center for Disease Control and Prevention. The objectives and procedures of the study were verbally explained to each participant and written informed consent was obtained.

\section{Patients and healthy controls}

The study was carried out on a total of 22 subjects from Dongting Lake Basin, Hunan Province, China. The profiles of participants is shown in Table 1. The participants included 10 healthy adult controls and 12 acute schistosomiasis patients. Patients were initially screened for Schistosoma spp. eggs in feces using the Kato-Katz method [9]. Then IgG specific to soluble egg antigen (SEA) and indirect hemagglutination antibody (IHA) in sera were detected. Acute schistosomiasis patients were diagnosed by positive results of fecal egg, IgG specific to SEA and IHA analyses. They also had a fever or fatigue accompanied by tenderness in the liver region and had been in contact with cercariae in water in the last 3 months. Moreover, they had no history of schistosome infection. Healthy controls did not display clinical symptoms of schistosome infection and produced negative laboratory results. All participants were free from HBV and $\mathrm{HCV}$.

\section{Flow cytometry analysis}

Peripheral blood mononuclear cells (PBMCs) were collected and isolated by Ficoll-density gradient centrifugation. PBMCs were immuno-stained for $30 \mathrm{~min}$ with the following antibodies, Tfh cells: CD4-PE, ICOS-FITC (eBioscience, San Diego, CA,USA), CXCR5-APC and PD-1 PE-Cy7 (BioLegend, San Diego, CA, USA); circulating B cells: CD4-FITC, CD19-APC and CD27-PE. The stained cells were then assessed using a CyAn ADP cytometer (Beckman Coulter, Lambertville, NJ, USA) and data were analyzed with FlowJo software.
Table 1 Participant profiles

\begin{tabular}{|c|c|c|c|c|c|c|}
\hline $\begin{array}{l}\text { No. } \\
\text { participant }\end{array}$ & Gender & $\begin{array}{l}\text { Age } \\
\text { (years) }\end{array}$ & Occupation & $\begin{array}{l}\text { Schistosoma } \\
\text { eggs in faeces }\end{array}$ & $\mathrm{HA}^{\mathrm{c}}$ & $\begin{array}{l}\text { SEA } \\
\operatorname{lgG}^{d}\end{array}$ \\
\hline$\overline{\mathrm{P} 1^{\mathrm{a}}}$ & $M$ & 24 & Peasant & + & + & + \\
\hline P2 & M & 21 & Peasant & + & + & + \\
\hline P3 & M & 45 & Fisherman & + & + & + \\
\hline P4 & M & 31 & Fisherman & + & + & + \\
\hline P5 & M & 51 & Fisherman & + & + & + \\
\hline P6 & M & 48 & Worker & + & + & + \\
\hline P7 & M & 48 & Fisherman & + & + & + \\
\hline P8 & M & 24 & Peasant & + & + & + \\
\hline P9 & M & 44 & Fisherman & + & + & + \\
\hline P10 & M & 28 & Fisherman & + & + & + \\
\hline P11 & M & 48 & Fisherman & + & + & + \\
\hline P12 & M & 49 & Fisherman & + & + & + \\
\hline $\mathrm{H} 1^{b}$ & M & 51 & Peasant & - & - & - \\
\hline $\mathrm{H} 2$ & M & 54 & Worker & - & - & - \\
\hline H3 & M & 42 & Doctor & - & - & - \\
\hline $\mathrm{H} 4$ & M & 21 & Worker & - & - & - \\
\hline H5 & M & 52 & Worker & - & - & - \\
\hline $\mathrm{H} 6$ & M & 44 & Worker & - & - & - \\
\hline $\mathrm{H} 7$ & M & 34 & Worker & - & - & - \\
\hline $\mathrm{H} 8$ & M & 28 & Peasant & - & - & - \\
\hline H9 & M & 45 & Doctor & - & - & - \\
\hline $\mathrm{H} 10$ & $M$ & 52 & Peasant & - & - & - \\
\hline
\end{tabular}

Abbreviations: a ${ }^{\mathrm{P}} 1-12$, schistosomiasis patients; ${ }^{\mathrm{b}} \mathrm{H} 1-10$, healthy controls; 'Indirect hemagglutination antibody (IHA); ${ }^{d} \mathrm{lgG}$ specific to soluble egg antigen (SEA)

\section{RNA extraction and real-time PCR}

$\mathrm{CD}^{+} \mathrm{T}$ cells from PBMC were purified using human CD4 MicroBeads (Miltenyi Biotec, San Diego, CA,USA) in accordance with the instructions of kit. RNA from $\mathrm{CD} 4^{+} \mathrm{T}$ cells was extracted using Trizol reagent and cDNA was produced using Taqman reverse transcription kits (TaKaRa, Shiga, Japan). Real-time PCR was performed using SYBR Supermix (TaKaRa, Shiga, Japan) and a CFX96 analysis system (Bio-Rad, Richmond, CA, USA). Each sample was amplified in triplicate. The primer sequences were: IL-21 sense 5'-CAC AGA CTA ACA TGC CCT TCA T- $3^{\prime}$ and antisense $5^{\prime}$-GAA TCT TCA CTT CCG TGT GTT CT-3'; Bcl-6 sense 5'-AAG GCC AGT GAA GCA GAG A-3', and antisense 5'-CCG ATA GGC CAT GAT GTC T-3'; c-Maf sense 5'-CAA GCT AGA AGC GCC CC-3', and antisense 5'-AGT TCT GAT GCC ATT CTC CTG-3'; $\beta$-actin sense $5^{\prime}$ AGC GAG CAT CCC CCA AAG TT-3', and antisense 5'-GGG CAC GAA GGC TCA TCA TT-3'. The realtime PCR amplification conditions were: denaturation at $95{ }^{\circ} \mathrm{C}$ for $5 \mathrm{~min}$ followed by 40 cycles of $95{ }^{\circ} \mathrm{C}$ for $10 \mathrm{~s}$ 
and $60{ }^{\circ} \mathrm{C}$ for $30 \mathrm{~s}$. Fluorescence values were recorded at $60{ }^{\circ} \mathrm{C}$.

\section{Detection of IL-21 and IgG specific to S. japonicum antigen}

The levels of serum IL-21 were analyzed using a human IL-21 ELISA Ready-SET-Go kit (eBioscience, San Diego, CA, USA) according to the manufacturer's protocol. The levels of serum IgG specific to SEA, adult worm antigen and schistosomula antigen were determined by ELISA. SEA, adult worm antigen and schistosomula antigen were prepared as described previously [10]. Briefly, 96well plates were coated with $5 \mu \mathrm{g} / \mathrm{ml} \mathrm{SEA}$, adult worm antigen or schistosomula antigen in coating buffer overnight at $4{ }^{\circ} \mathrm{C}$. After washing and blocking, serum from schistosomiasis patients was added and HRP-conjugated goat anti-human IgG was used as the secondary antibody. All samples were analyzed in triplicate using the average absorbance at $450 \mathrm{~nm}$ to calculate concentrations.

\section{Statistical analysis}

Statistical differences between two groups were determined by independent t-test or Mann-Whitney $U$ test using SPSS19.0 software. Correlations between groups were analyzed using Spearman's rank correlation $\left(\mathrm{r}_{\mathrm{s}}\right)$. A two-sided $P$-value of $<0.05$ was considered statistically significant.

\section{Results}

\section{Clinical characteristics of study subjects}

Tweleve acute schistosomiasis patients (aged $38 \pm 11.7$ ) and 10 healthy controls (aged $42 \pm 11.2$ ) were enrolled in the study. There was no statistically significant difference in age between the acute schistosomiasis patients and healthy controls; all patients were male $\left(t_{(20)}=-0.789\right.$, $P=0.439)$.

\section{Characteristics of Tfh cells in acute schistosomiasis patients}

The percentage of circulating $\mathrm{CXCR} 5^{+} \mathrm{CD} 4^{+}$Tfh cells among $\mathrm{CD}^{+} \mathrm{T}$ cell population was monitored by flow cytometry (Fig. 1a). As shown in Fig. 1b, the frequency of $\mathrm{CXCR}^{+} \mathrm{CD} 4^{+}$Tfh cells was similar between acute schistosomiasis patients and the $\mathrm{HC}$ group. Next we compared activated peripheral Tfh $[11,12]$ cells $\left(\mathrm{PD}-1^{+} \mathrm{CXCR} 5^{+} \mathrm{CD} 4^{+}\right.$ Tfh and $\mathrm{ICOS}^{+} \mathrm{CXCR}^{+} \mathrm{CD} 4^{+}$Tfh cells) (Fig. 1c, e,). There was a significantly higher frequency of PD $-1^{+} \mathrm{CXCR} 5^{+} \mathrm{CD} 4^{+}$ Tfh cells in acute schistosomiasis patients compared with healthy control (Fig. 1d) $\left(t_{(20)}=-3.575, P=0.003\right)$. However, there was no statistically significant difference in the percentage of $\mathrm{ICOS}^{+} \mathrm{CXCR} 5^{+} \mathrm{CD} 4^{+}$Tfh cells between the acute schistosomiasis and $\mathrm{HC}$ groups (Fig. 1f) $\left(t_{(20)}=0.005, P=0.996\right)$.
Increased mRNA expression of IL-21 but not Bcl-6 or c-Maf Cytokine IL-21 and transcriptional factors Bcl-6 and cMaf play critical roles in the differentiation and function of Tfh cells [13-15]. We assessed the expression of Bcl-6, c-Maf and IL-21 mRNA in the CD4 ${ }^{+} \mathrm{T}$ cells of acute schistosomiasis patients and healthy controls (Fig. 2). Bcl-6 and c-Maf mRNA expression levels in $\mathrm{CD}^{+}{ }^{+} \mathrm{T}$ cells of patients were similar to those in controls (Fig. 2a, b). IL-21 is a typical cytokine produced by Tfh cells and can enhance production of antibodies by $\mathrm{B}$ cells. The mRNA level of IL-21 was higher in patients compared to healthy controls (Fig. 2c) $\left(t_{(8)}=-6.791 P=0.0005\right)$. Moreover, the level of serum IL-21 was significantly higher in patients than in HCs (Fig. 2d) $\left(t_{(20)}=-2.001, P=0.049\right)$.

\section{FACS analysis of different subsets of B cells}

Tfh cells are mainly responsible for assisting B cells to induce antibody response. Therefore, we characterized the frequency of observation of different stages of B cells by flow cytometry (Fig. 3a). As shown in Fig. $3 \mathrm{~b}$, the percentage of $\mathrm{CD} 27^{+} \mathrm{CD} 19^{+} \mathrm{CD} 4^{-}$memory $B$ cells [16-18] in acute schistosomiasis patients was significantly higher than in $\mathrm{HCs}\left(t_{(20)}=2.250, P=0.036\right)$. In contrast, the percentage of $\mathrm{CD} 27^{-} \mathrm{CD} 19^{+} \mathrm{CD} 4^{-}$naïve $\mathrm{B}$ cells [19] in patients was lower than in the HCs (Fig. 3c) $\left(t_{(20)}=-2.396, P=0.026\right)$.

\section{Relationship between the percentage of PD $-1^{+}$CXCR5 ${ }^{+} \mathrm{CD}^{+}$Tfh cells and other clinical parameters in acute schistosomiasis patients}

Given Tfh cells can promote B cells to secrete antibodies [20], we determined whether IgG specific to S. japonicum antigen correlated with B cells or Tfh cells in patients. There was no significant correlation between the percentages of circulating $\mathrm{PD}-1^{+} \mathrm{CXCR} 5^{+} \mathrm{CD} 4^{+}$Tfh cells and $\mathrm{CD}_{2} 7^{+} \mathrm{CD} 19^{+} \mathrm{CD} 4^{-}$memory $\mathrm{B}$ cells in patients (Fig. 4a) $\left(r_{\mathrm{s}}=0.392, P=0.208\right)$. There was a tendency towards correlation between the percentage of PD-1 ${ }^{+} \mathrm{CXCR} 5^{+} \mathrm{CD} 4{ }^{+}$Tfh cells and the level of IgG specific to S. japonicum antigen (Fig. 4b-d), but statistical significance was not reached $\left(\mathrm{r}_{\mathrm{s}}=0.107, P=0.630 ; r_{\mathrm{s}}=0.021\right.$, $\left.P=0.948 ; r_{\mathrm{s}}=0.189, P=0.557\right)$. Furthermore, no statistically significant correlation was observed between $\mathrm{CD} 27^{+} \mathrm{CD} 19^{+} \mathrm{CD} 4^{-}$memory B cells and the level of IgG specific to S. japonicum antigen (Fig. 4e-g) $\left(r_{\mathrm{s}}=0.270\right.$, $\left.P=0.397 ; r_{\mathrm{s}}=0.343, P=0.276 ; r_{\mathrm{s}}=0.140, P=0.665\right)$.

\section{Discussion}

At present, praziquantel remains highly effective in treating schistosomiasis. However, drug resistance and decreased susceptibility occur with long-term use of drugs [21]. Therefore, effective vaccines against schistosome infection are necessary. Tfh cells promote antibody 


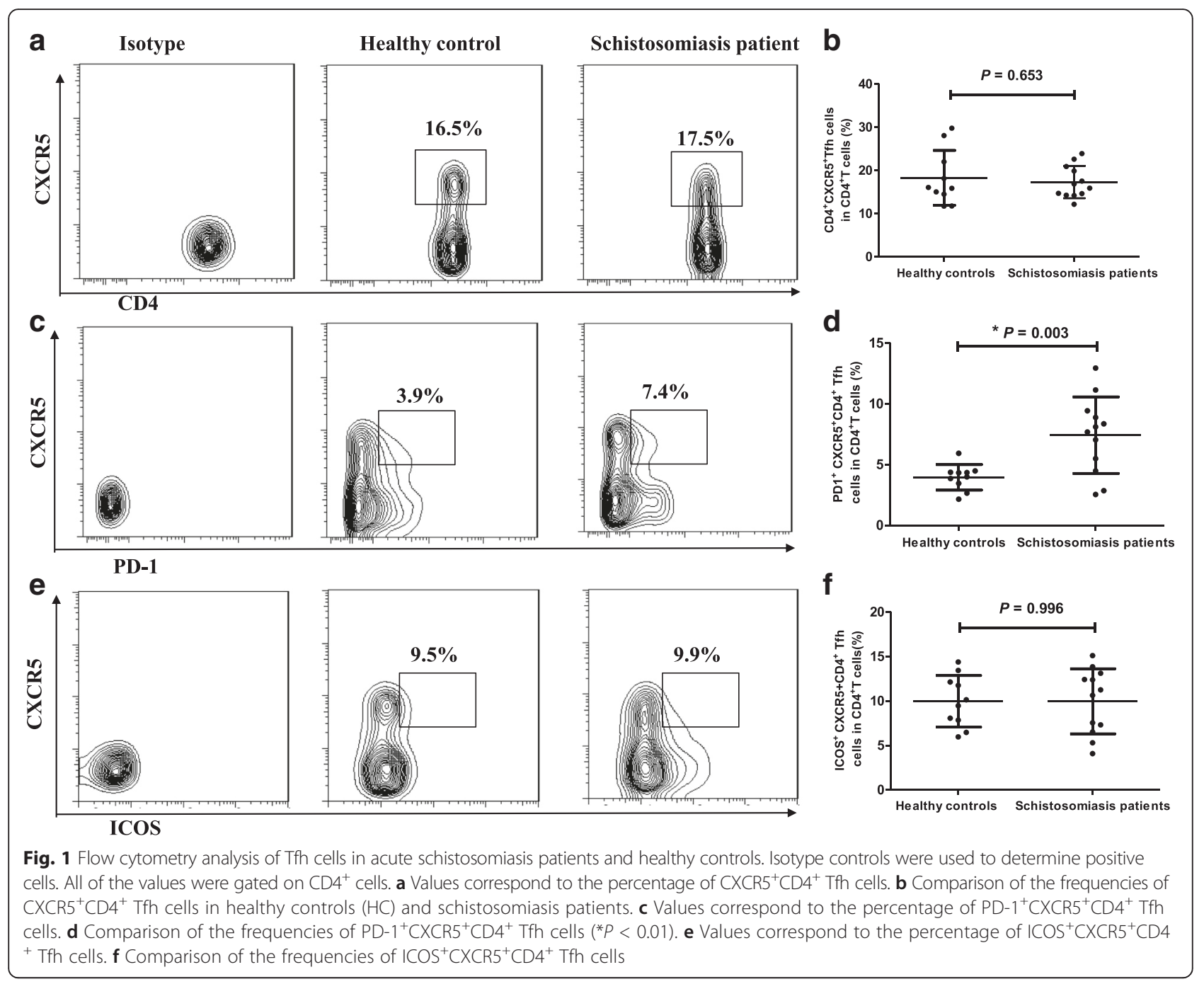

production through interaction with B cells [22]. Tfh cells play an important role in long-term humoral immunity and have proven to be one of the important contributors to the effect of successful vaccines [23]. However, the role of Th cells in schistosomiasis patients is not well understood and this limits our ability to develop anti-schistosome vaccines. Previous studies revealed an increased frequency of Tfh cells in mice with schistosome infection [6, 24]. Both our previous study and other research focused on the characteristics of peripheral Tfh cells in chronic schistosomiasis patients $[7,25]$. However, whether the number of Tfh cells
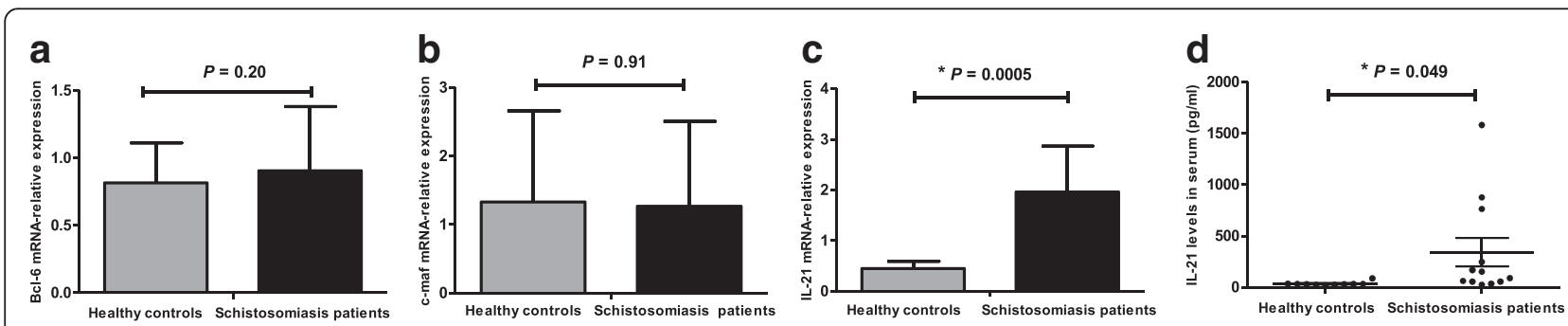

Fig. 2 Analysis of transcription factors and IL-21 levels in acute schistosomiasis patients and HCs. Real-time PCR analysis transcription factors and IL-21. a Detection of Bcl-6 mRNA expression. b Detection of c-Maf mRNA expression. c Detection of IL-21 mRNA expression $\left({ }^{*} P<0.01\right)$. d Levels of IL-21 in sera from schistosomiasis patients and HCS $\left({ }^{*} P<0.05\right)$ 


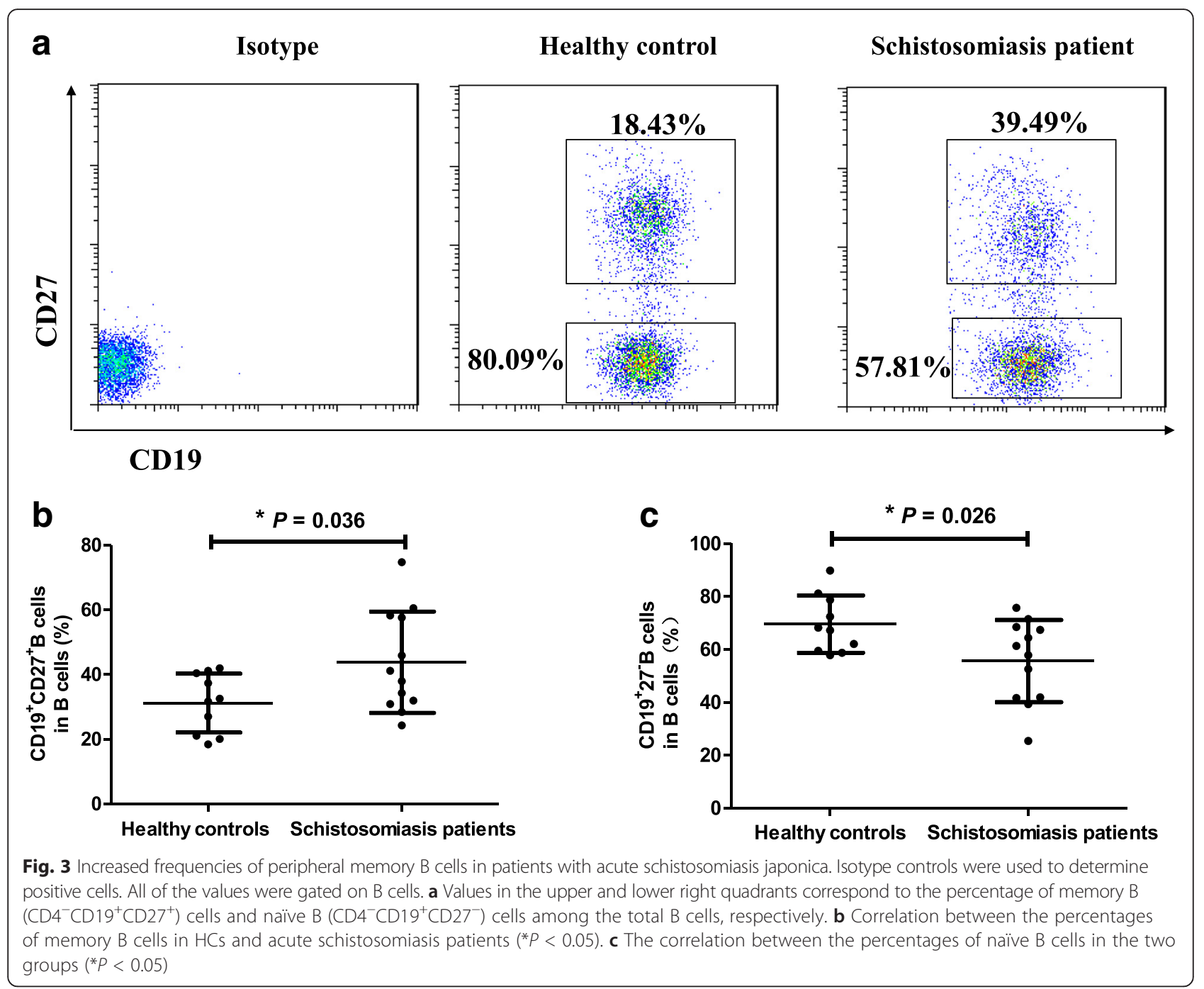

increase in acute schistosomiasis patients remains unknown. The present study thus extended previous work to assess Tfh cells in acute schistosomiasis patients.

No obvious fluctuation in the frequency of CXCR5 ${ }^{+} \mathrm{CD} 4{ }^{+}$Tfh cells was observed between acute schistosomiasis patients and the $\mathrm{HC}$ group. To further identify whether this subset of cells plays a role in acute schistosome infection, the expression profiles of two markers associated with Tfh cell function (PD-1, ICOS) were determined. A significantly higher frequency of PD-1 ${ }^{+} \mathrm{CXCR} 5^{+} \mathrm{CD} 4{ }^{+}$Tfh cells was found in acute schistosomiasis patients than in HCs. This might suggest that PD-1 ${ }^{+}$Tfh cells are associated with production of antibodies against the parasite because PD-1 has been demonstrated to regulate the formation of GCs and the survival of $B$ cells [26, 27]. In addition, the relationship between PD $-1^{+} \mathrm{CXCR}^{+} \mathrm{CD}^{+}$Tfh cells and IgG specific to $S$. japonicum antigen in patients' serum was explored, but no statistical correlation was found. In contrast to this result, our previous study of chronic patients showed a positive correlation between $\mathrm{PD}-1^{+} \mathrm{CXCR} 5^{+} \mathrm{CD} 4^{+}$Tfh cells and IgG specific to SEA [7]. This discrepancy might be due to distinguished immune responses in chronic and acute stages of the disease, but the specific mechanism requires further research. Our previous study found increased expression of ICOS in the Tfh cells of chronic schistosomiasis patients relative to HCs [7]. However, there was no significant difference between the levels of these two parameters in acute patients and HCs. In a mouse model, it was found that the expression of ICOS in Tfh cells was involved in the formation of liver granuloma [6]. Compared with the control group, liver granuloma significantly enlarged in the chronic phase, but not in the acute phase in the ICOS transgenic mouse model infected with S. japonicum [28]. Thus we speculate that the livers of chronic schistosomiasis patients have 


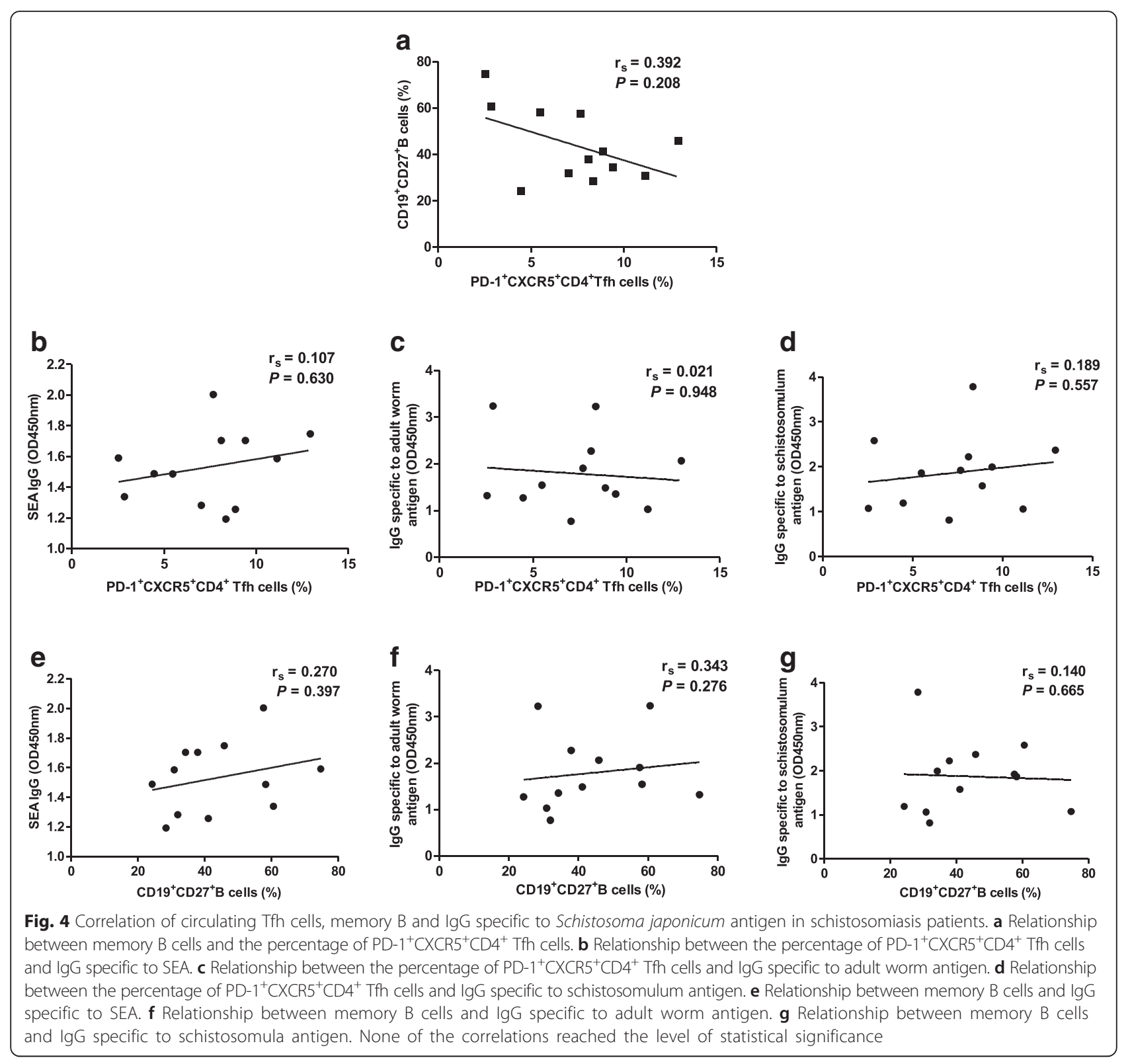

varying degrees of fibrosis induced by ICOS expression. The expression of ICOS might not be detectably upregulated in acute schistosomiasis patients because their livers have only slight damage.

The expression of IL-21 mRNA and the IL-21 levels in serum were significantly higher in acute schistosomiasis patients than in HCs. IL-21 is a critical cytokine released by Tfh cells, which can help with Tfh development and antibody production $[29,30]$. The upregulated expression of IL-21 might imply an enhanced function of Tfh cells in acute phase infection. Unlike the situation in chronic patients, there was no significant positive correlation between PD $-1^{+}$CXCR $5{ }^{+} \mathrm{CD} 4^{+}$Tfh cells and levels of serum IL-21. Moreover, the mRNA expression of the transcription factors Bcl-6 and c-Maf, which are essential for Tfh cell differentiation, also showed no apparent upregulation. The latter is in accordance with our previous study in chronic schistosomiasis patients. It has been demonstrated that GC Tfh cells expressed high levels of Bcl-6 while circulating Tfh cells failed to express increased levels of Bcl-6 [20].

A higher percentage of memory B cells was observed in acute schistosomiasis patients relative to HCs. This is in accordance with the previous observation [25] that memory B cells and plasma cells were increased in schistosomiasis patients. However, there was no statistical correlation between memory B cells and levels of IgG specific to $S$. japonicum antigen. It may be that other subsets of B cells, but not memory B cells, correlate with IgG specific to $S$. japonicum antigen in schistosomiasis patients. 


\section{Conclusions}

This study assessed the changes in circulating Tfh cells and B cells in acute schistosomiasis patients. Better understanding the differences in immune mechanisms between acute and chronic schistosomiasis patients will be helpful for vaccine design to prevent schistosomiasis.

\section{Abbreviations}

ELISA, enzyme-linked immunosorbent assay; GC, germinal centers; HC, healthy control; IHA, indirect hemagglutination antibody; PBMCs, peripheral blood mononuclear cells; SEA, soluble egg antigens; Tfh, T follicular helper

\section{Acknowledgements}

The authors are grateful to Professor Yongkang He for helping collect samples in Prevention of schistosomiasis in Hunan Province, China.

\section{Funding}

This work was supported by the grants from the National Natural Science Foundation (No. 81371841 to JC, No. 81202301 to YW) and the Fourth Round of Three-Year Public Health Action Plan of Shanghai, China (No. 15GWZK0101 to JC). The funders had no role in study design, data collection and analysis, decision to publish, or preparation of the manuscript.

\section{Availability of data and materia}

Not applicable.

\section{Authors' contributions}

Conceived and designed the experiments: YZ, YW, YJ, JC. Performed the experiments: YZ, YW, YJ. Analyzed the data: YZ, YW, JY, HL, YS. Wrote the paper: $Y Z, J C, Y W, W P$. All authors read and approved the final version of the manuscript.

\section{Competing interests}

The authors declare that they have no competing interests.

\section{Consent for publication}

Not applicable.

\section{Ethics approval and consent to participate}

Ethical approval for this study was obtained from the Ethics Committee of the National Institute of Parasitic Diseases, Chinese Center for Disease Control and Prevention (reference no. 2012-12). The objectives and procedures of the study were verbally explained to each participant and written informed consent was obtained.

\section{Author details}

${ }^{1}$ National Institute of Parasitic Diseases, Chinese Center for Disease Control and Prevention, Shanghai 200025, China. ${ }^{2}$ Key Laboratory of Parasite and Vector Biology, $\mathrm{MOH}$, Shanghai 200025, China. ${ }^{3}$ National Center for International Research on Tropical Diseases, Shanghai 200025, China. ${ }^{4} \mathrm{WHO}$ Collaborating Center for Tropical Diseases, Shanghai 200025, China. ${ }^{5}$ Department of Pathogenic Biology, Binzhou Medical University, Yantai 264003, Shandong, China. 'Department of Pathogenic Biology and Immunity, Xuzhou Medical University, Xuzhou 221004, Jiangsu, China.

Received: 9 February 2016 Accepted: 20 May 2016

Published online: 06 June 2016

\section{References}

1. Ross AG, Bartley PB, Sleigh AC, Olds GR, Li Y, Williams GM, et al. Schistosomiasis. N Engl J Med. 2002;346:1212-20.

2. Gryseels B, Polman K, Clerinx J, Kestens L. Human schistosomiasis. Lancet. 2006:368:1106-18.

3. Crotty S. Follicular helper CD ${ }^{4}$ T cells (TFH). Annu Rev Immunol. 2011;29:621-63.

4. Crotty S. T follicular helper cell differentiation, function, and roles in disease. Immunity. 2014;41:529-42.

5. Ma CS, Deenick EK, Batten M, Tangye SG. The origins, function, and regulation of T follicular helper cells. J Exp Med. 2012;209:1241-53.
6. Chen X, Yang X, Li Y, Zhu J, Zhou S, Xu Z, et al. Follicular helper T cells promote liver pathology in mice during Schistosoma japonicum infection. PLoS Pathog. 2014;10:e1004097.

7. Zhang YM, Jiang YY, Wang YJ, Liu H, Shen YJ, Yuan ZY, et al. Higher frequency of circulating PD- $1^{\text {high }} \mathrm{CXCR} 5^{+} \mathrm{CD} 4^{+}$Tfh cells in patients with chronic schistosomiasis. Int J Biological Sci. 2015;11:1049-55.

8. Feng J, Lu L, Hua C, Qin L, Zhao P, Wang J, et al. High frequency of CD4 ${ }^{+}$ CXCR5 ${ }^{+}$TFH cells in patients with immune-active chronic hepatitis B. PLoS One 2011:6:e21698.

9. Katz N, Chaves A, Pellegrino J. A simple device for quantitative stool thicksmear technique in schistosomiasis mansoni. Rev Inst Med Trop Sao Paulo. 1972;14:397-400.

10. Chensue SW, Boros DL. Modulation of granulomatous hypersensitivity I. Characterization of T lymphocytes involved in the adoptive suppression of granuloma formation in Schistosoma mansoni-infected mice. J Immunol. 1979;123:1409-14

11. He J, Tsai LM, Leong YA, Hu X, Ma CS, Chevalier N, et al. Circulating precursor CCR7 ${ }^{\text {lo PD }-1^{\text {hi }}} \mathrm{CXCR5}^{+} \mathrm{CD} 4^{+} \mathrm{T}$ cells indicate $\mathrm{Tfh}$ cell activity and promote antibody responses upon antigen reexposure. Immunity. 2013:39(4):770-81.

12. Locci M, Havenar-Daughton C, Landais E, Wu J, Kroenke MA, Arlehamn CL, et al. Human circulating PD-1+CXCR3 ${ }^{-} \mathrm{CXCR}^{+}$memory Tfh cells are highly functional and correlate with broadly neutralizing HIV antibody responses. Immunity. 2013;39:758-69.

13. Kroenke MA, Eto D, Locci M, Cho M, Davidson T, Haddad EK, et al. Bcl6 and Maf cooperate to instruct human follicular helper CD4 T cell differentiation. J Immunol. 2012:188:3734-44.

14. Eto D, Lao C, DiToro D, Barnett B, Escobar TC, Kageyama R, et al. IL-21 and IL-6 are critical for different aspects of $B$ cell immunity and redundantly induce optimal follicular helper CD4 T cell (Tfh) differentiation. PloS One. 2011;6:e17739.

15. Nakayamada S, Poholek AC, Lu KT, Takahashi H, Kato M, Iwata S, et al. Type I IFN induces binding of STAT1 to Bcl6: divergent roles of STAT family transcription factors in the $\mathrm{T}$ follicular helper cell genetic program. J Immunol. 2014;192:2156-66

16. Tangye SG, Avery DT, Hodgkin PD. A division-linked mechanism for the rapid generation of Ig-secreting cells from human memory B cells. J Immunol. 2003;170:261-9.

17. Perez ME, Arana E. Donors define whether $C D 19^{+} C D 27^{+}$tonsillar B cells are mostly memory or germinal-center B cells. Immunol Cell Biol. 2015:93:431-2.

18. Basha S, Pichichero ME. Poor memory B cell generation contributes to nonprotective responses to DTaP vaccine antigens in otitis-prone children. Clin Exp Immunol. 2015;182:314-22.

19. Matsuda Y, Haneda M, Kadomatsu K, Kobayashi T. A proliferation-inducing ligand sustains the proliferation of human naïve $\left(\mathrm{CD} 27^{-}\right) \mathrm{B}$ cells and mediates their differentiation into long-lived plasma cells in vitro via transmembrane activator and calcium modulator and cyclophilin ligand interactor and B-cell mature antigen. Cell Immunol. 2015;295:127-36.

20. Morita R, Schmitt N, Bentebibel SE, Ranganathan R, Bourdery L, et al. Human blood $\mathrm{CXCR}^{+} \mathrm{CD}^{+} \mathrm{T}$ cells are counterparts of $\mathrm{T}$ follicular cells and contain specific subsets that differentially support antibody secretion. Immunity. 2011;34:108-21.

21. Wang W, Wang $L$, Liang YS. Susceptibility or resistance of praziquantel in human schistosomiasis: a review. Parasitol Res. 2012;111:1871-7.

22. Breitfeld D, Ohl L, Kremmer E, Ellwart J, Sallusto F, Lipp M, et al. Follicular B helper T cells express CXC chemokine receptor 5, localize to B cell follicles, and support immunoglobulin production. J Exp Med. 2000;192:1545-52.

23. Hu J, Havenar-Daughton C, Crotty S. Modulation of SAP dependent T:B cell interactions as a strategy to improve vaccination. Curr Opin Virol. 2013;3:363-70.

24. Hams E, McCarron MJ, Amu S, Yagita H, Azuma M, et al. Blockade of B7-H1 (programmed death ligand 1) enhances humoral immunity by positively regulating the generation of $\mathrm{T}$ follicular helper cells. J Immunol. 2011;186: 5648-55.

25. Chen X, Li W, Zhang Y, Song $X, X u L, X u$ Z, et al. Distribution of peripheral memory $T$ follicular helper cells in patients with schistosomiasis japonica. PLoS Negl Trop Dis. 2015:9:e0004015.

26. Good-Jacobson KL, Szumilas CG, Chen L, Sharpe AH, Tomayko MM, Shlomchik MJ. PD-1 regulates germinal center B cell survival and the formation and affinity of long-lived plasma cells. Nat Immunol. 2010;11:535-42.

27. Keir ME, Butte MJ, Freeman GJ, Sharpe AH. PD-1 and its ligands in tolerance and immunity. Annu Rev Immunol. 2008;26:677-704.

28. Xia CM, Pu XK Gong W, Luo W, Zhang HQ Deng ZB, et al. [Immune response and immunopathology in inducible costimulatory molecule (ICOS) 
transgenic mice infected with Schistosoma japonicum]. Zhongguo Ji Sheng Chong Xue Yu Ji Sheng Chong Bing Za Zhi. 2006;24:349-52 (in Chinese).

29. Ozaki K, Spolski R, Feng CG, Qi CF, Cheng J, Sher A, et al. A critical role for IL-21 in regulating immunoglobulin production. Science. 2002;298:1630-4.

30. Zotos D, Coquet JM, Zhang Y, Light A, D'Costa K, Kallies A, et al. IL-21

regulates germinal center $B$ cell differentiation and proliferation through a $B$ cell-intrinsic mechanism. J Exp Med. 2010;207:365-78.

Submit your next manuscript to BioMed Central and we will help you at every step:

- We accept pre-submission inquiries

- Our selector tool helps you to find the most relevant journal

- We provide round the clock customer support

- Convenient online submission

- Thorough peer review

- Inclusion in PubMed and all major indexing services

- Maximum visibility for your research

Submit your manuscript at www.biomedcentral.com/submit 